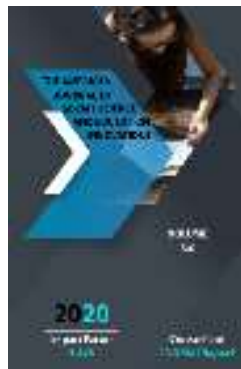

\section{The Necessity Of Educating An Enlightened Generation Through The Transformation Of Scientific And Religious Values}

Qambarov Abdumutal Axadjonovich Associate Professor Of Fergana State University, Candidate Of Philosophical Sciences, Uzbekistan
Journal Website: http://usajournalshub.c om/index,php/tajssei

Copyright: Original content from this work may be used under the terms of the creative commons attributes 4.0 licence.

\title{
ABSTRACT
}

The article analyzes the views on the development of scientific and practical knowledge on the creation of an environment of freedom and competition in the education system in order to show the value of science in society and the role of scientific values in social development.

\section{KEYWORDS}

Scientific knowledge, religious knowledge, values, enlightenment, folk art, thinking, worldview, worldview

\section{INTRODUCTION}

There is a growing need to educate an enlightened generation through the transformation of scientific and religious values in the process of a new stage of development of society. For this purpose, all the opportunities and conditions in our country have been implemented at the required level.
In the process of creating a high level of enlightenment in society through the transformation of scientific and religious values, it is necessary to effectively use the sympathy of secular and religious science, scientific results, teaching and learning methodologies of developed countries, as well as national customs and traditions. Our national customs and traditions are ingrained 
in social life and works to enhance the dignity of the individual.

In order to further develop the social sphere through the reforms being carried out in our country today, "... it is necessary to further improve the system of science, modern and continuing education. There is an adage among our nation: "Education and upbringing begins from the birth." Only enlightenment leads man to perfection and society to progress "[1.29]. Therefore, the process of the education system must be successtion and based on certain principles. "Great emphasis is placed on investing in the full cycle of education, that is, investing in the upbringing of a child between the ages of 3 and 22 in developed countries. Because this investment will bring 15-17 times more benefits to society. In our case, this figure is only 4 times "[1.30]. So there is a need to create scientific values and apply them to society through focusing on human capital. By appreciating the fact that our great enlightened ancestor Abdullah Avloni "The strength and breadth of human thinking depends primarily on the education of teachers" [1.353], it is possible to create an enlightened environment in society. That is why today it is necessary to reform and improve the system of education and culture. . Knowledge and high spiritual maturity has an important role in the of civil society's development. For implementing this, firstly, "it is necessary to increase the authority of higher education institutions, increase the number of non-governmental educational institutions, involve highly qualified personnel to the field and increase competition" [1.19]. Secondly, the development of mental and spiritual capacity is another continuous principle. Only the people who are highly educated, mentally fit and physically strong can cross the path of independence and development. In the third place, It is the consistent continuation of the sources of national spirituality and the rich traditions of our nation. This is a social necessity, because in order to bring our country to a high level of development, we need "knowledgeable, intelligent, enlightened people who can easily discuss with scientists like famous, whether in the fields of economics, politics, history, spirituality" [2.5]. So It means that the urgent task of today is to bring up an educated and enlightened generation and to change the meditation of society. In order to bring up an enlightened generation at a new stage of development, first of all, it is necessary to "organize the general secondary education system on the basis of today's requirements, create all conditions for the full development of our children. ... It is necessary to improve efforts to create equal opportunities for studying at higher education "[1.30].

In order to appreciate science in society and demonstrate the role of scientific values in social development it is also important to create an environment of independent and competition in the education system. Members of society need to be educated, highly moral, cultured, have a deep scientific outlook and thinking at the new stage of development of Uzbekistan. On this issue, the system of educational institutions is an important tool in shaping the scientific outlook of young people. That is why, the positive factors influencing the rise of the worldview of young people - the system of values, the role of secular knowledge in this system, what knowledge is needed in the education of an enlightened generation and the methods of their transmission, certain changes in human values, national and universal values. Although spiritual-moral and axiological values are shown to be important factors in the upbringing of an enlightened person, it should not be limited with this. Because it is manifested in the upbringing of an enlightened person and in ensuring their full participation in the development of society. 
The state of the social environment plays an important role in educating members of society. Today it is necessary to determine the basic structure of spiritual, moral and axiological values necessary for the upbringing of an enlightened generation. Also, the development of convenient and modern technologies for the inculcation of established values in the human mind is still relevant.

\section{MATERIALS AND METHODS}

In fact, enlightenment is closely related to science and knowledge acquisition. Shortly put, an educated person can be described as an enlightened person. Knowledge is a necessary component of an individual, it helps a person to learn and activates his desire for an independent life. The acquisition of knowledge in a secular or religious context is equated with high happiness, perfection, perfection and dignity, with merit. For the philosopher Plato said, "There is nothing stronger in the universe than knowledge. Knowledge is more important than any pleasure or anything else." He said, "Man lives only because of knowledge. Knowledge and thinking are the basis of human life, "said Gegel. Indeed, among all social values, the attitude to knowledge is high, and the position of man in society, his perfection, is directly related to knowledge. The thinker Imam Bukhari, on the other hand, stated that "there is no salvation in the world other than knowledge" [4.156]. The role of science and enlightenment is important in the new stage of development of Uzbekistan. Science, education is one of the most powerful factors determining the development of society Education - theoretical diligence teaches virtue, education - teaches virtuous moral qualities. High moral qualities are the knowledge, wisdom, and plurality of goals that are manifested in human behavior, the pursuit of action, love, exaltation, and the love of justice. "A wise man is one who has a sharp intellect and with a virtue." People who are intelligent are those who are virtuous, sharpwitted, devoted to useful work, and have a great talent for discovering what is necessary "[5.182]. We should mention that "First of all, our great compatriots - the founder of the algorithm Muhammad Khorezmi, encyclopedic scientist Ahmad Fergani, Abu Rayhan Beruni, who made a great contribution to the development of geodesy and mineralogy, Ibn Sina, known in the West as Avicenna, statesman and great astronomer Mirzo Ulugkirbek. names "[1.208-209]. Today, developing work is being done in the field of education, which is the basis for the development of the intellectual potential of our society, the education of an enlightened generation. The following work is being carried out on the basis of the State National Program of School Education:

- Radical renovation and reconstruction of secondary school buildings and engineering communication infrastructure;

- Equipping schools with modern teaching and learning equipment, computers, textbooks and teaching materials;

- Improved educational standards and curriculum; the provision of secondary schools with qualified teaching staff, the creation of an effective system of training, retraining and advanced training of teachers, the promotion of their work has been strengthened.

\section{RESULT AND DISCUSSION}

Thus, the reform and modernization of the education system was an important step in increasing their place and role in educating an enlightened generation. In this regard, Uzbekistan has contributed to the development of the Islamic world in the field of science and technology by further improving and developing the activities of research 
institutions, research and production enterprises and innovation centers in Islamic countries by proposing the idea of "Education and enlightenment - the path to peace and prosperity." In fact, only when a country invests in science will that society prosper and people become enlightened and have good faith.

The processes of reforms and modernization that determine the development of a renewed Uzbekistan put great challenges to society and all its systems. This also applies directly to education. It can be said that the radical reforms launched in the last four years in the field of education are important in terms of improving its quality, creating conditions for students to acquire in-depth knowledge of the specialty, the formation of harmoniously developed individuals, modernization of continuing and general secondary education.

The process of reforms and modernization initiated to create a system of continuing education and upbringing serves to implement a policy of transparency and openness, to strengthen their mutual responsibility, to increase the role of all actors in this area. For example, problems and shortcomings that existed in the past are disappearing on their own.

The main task today is not to weaken the reforms that have begun so rapidly, but to urgently address the many problems and shortcomings that have accumulated in the field of education. Effective use of the experience of foreign countries is also important in the modernization of education. For this purpose, it is possible to cite "the recent establishment of new scientific and innovative structures in our country - the Center for Genomics and Bioinformatics, the International Institute of Solar Energy, the
Center for High Technologies, the UzbekJapanese Youth Innovation Center" [1.210].

The application of foreign experience will prevent mistakes in reforming and modernizing the education system, improve the quality of education, create a single educational space, improve the system of continuing education, allow us to clearly feel our national position, historical values, national characteristics. After all, we must always keep in mind that they are an integral part of our national culture.

It is possible to have a positive impact on social consciousness by educating an enlightened generation based on a combination of scientific and religious values. The content and characteristics of the process of educating enlightened youth with deep thinking and a broad outlook, as well as directly related to the tasks of civil society.

The 21st century is a century in the history of mankind in which human potential, intellect and science have risen to incomparable greatness. As a result of the modernization of science and technology and the rapid progress of globalization, human knowledge and intellectual abilities rise to a higher level, resulting in innovative conditions and opportunities for the enrichment of his intellect, thinking ability, spirituality and thinking.

Appreciating and paying attention to the knowledge acquired gradually makes learning a social need. People's mentality, his activity and thinking ability, the content of his spiritual life develops and rises. This occurs under the influence of biological and social factors, which means that "Knowledge is the nourishment of the human mind and spirit" [6.24]. As a person's level of religious and secular knowledge develops and improves, he attains so much perfection that his mind and thinking 
are capable of forming high feelings such as goodness, tolerance, love, ability to see longterm goals, and quick thinking.

At a new stage of development of society is to create an atmosphere of peace, interethnic harmony and religious tolerance in society by educating an enlightened generation through the transformation values of scientific and religion. It should be noted that the head of our state has his own way and unanimous opinion in this regard "Uzbekistan has always been faithful to its traditions in the field of interethnic harmony and religious tolerance and will never deviate from this path. In our country, priority is given to strengthening the atmosphere of mutual respect, friendship and harmony between representatives of different nationalities and religions "[1.54]. It is possible to ensure harmony and religious tolerance between religious denominations by values and respect for science and religion in the members of the society, and by creating a harmony of science and religion.

Ўзбекистоннинг илм ва динни бирдай қадрлаш ва уларни уйғун холда ривожланишини таъминлаш сиёсати жахон хамжамияти томонидан хам тасдиқланмоқда. Ушбу ишларнинг натижаси сифатида “Бирлашган Миллатлар Ташкилоти Бош Ассамблеясининг ялпи мажлиси томонидан мухим бир хужжат - “Маърифат ва диний бағрикенглик” резолюцияси қабул қилинишини келтириш мумкин. Ушбу резолюцияни қабул қилиш ташаббуси 2017 йил сентябрь ойида Бош Ассамблеянинг 72сессиясида Ўзбекистон томонидан илгари сурилган эди"[1.55].

National cultural heritage, where there is a need to evaluate and study as a scientific value, folk art is considered important in social development. Because folklore "the art of bakhshi, which expresses the national identity of different peoples, their language and way of life, traditions and customs, is valuable for all of us as an integral part of universal culture" [1.134].

\section{CONCLUSION}

In today's globalization position, the transformation of art into a commercial medium, the growing influence of popular culture on it, the growing need to preserve national values and form a value attitude to them In short, the need to educate an enlightened generation through the transformation of scientific and religious values in the new stage of development of society remains one of the important tasks in combating threats such as religious extremism and international terrorism, bigotry. If there are educated and religiously enlightened people in every society, there will be no national and religious conflicts, no contradictions. Therefore, at a new stage of development is to create an environment of peace, interethnic harmony and religious tolerance in society by educating an enlightened generation through the transformation of scientific and religious values. It should be noted that the head of our state has his own way and unanimous opinion in this regard.

\section{REFERENCES}

1. Mirziyoev Sh.M. The work of a nation with a great intention will also be great, its life will be bright and its future will be prosperous. - Tashkent .: Uzbekistan. Volume 32019.

2. Karimov I.A. There is no future without historical memory. Journal of Communication, 1998. № Issue 5.

3. Toshboltaev M. Scientist, science, discovery and development. -Tashkent .: Fan. 2012. 
4. Abdullaev A. There is no salvation other than knowledge. - Tashkent .: Tashkent Islamic University. 2017.

5. Abu Nasr Faroobi. A city of noble people. Tashkent .: Abdulla Qodiriy. 1993.

6. Ziyomuhammadov B. Basics of skill. Tashkent .: Medicine book. 2009. 